\title{
PENERAPAN KOREKSI FISKAL BIAYA ENTERTAINMENT TERHADAP LAPORAN LABA RUGI PERUSAHAAN PADA PT BERKAH KARUNIA KREASI
}

\author{
Sabil, Ahmad Isbahul Falah, Dwiyatmoko Puji Widodo, Amin Setio Lestiningsih \\ AMK BSI Jakarta,Indonesia \\ sabil.sbl@bsi.ac.id
}

\begin{abstract}
Abstrak
Koreksi fiskal biaya entertainment terhadap laba rugi sangat mempengaruhi pendapatan atau penghasilan bersih yang akan dihitung dengan tarif pajak. Pencatatan biaya entertainment harus mempunyai bukti yang kuat apabila tidak ada bukti yang kuat maka akan dikoreksi fiskal, metode yang digunakan untuk menguji pengaruh koreksi fiskal biaya entertainment terhadap laba rugi adalah metode observasi, dokumentasi, wawancara, dan studi pustaka dengan metode analisanya berupa analisis kuantitatif yaitu metode analisis data menggunakan analisis statistik, dengan koreksi fiskal biaya entertainment sebagai variabel independen (X) dan laba rugi sebagai variabel dependen (Y) hasil penelitian menunjukkan bahwa nilai korelasi sebesar 0,781 dengan probabilitas 0,067 yang berarti variabel independen dan dependen memiliki hubungan yang kuat dan signifikan. Sedangkan kontribusi koreksi fiskal biaya entertianment pada laba rugi sesuai dengan uji determinasi adalah 0,610 atau 61\%. Hasil uji t juga menunjukkan thitung 2,503 dan tabel 2,131 yang berarti pengaruh variabel $\mathrm{X}$ terhadap variabel $\mathrm{Y}$ tetapi tidak signifikan. Hasil regresi adalah $\mathrm{Y}=-0,300+$ 2,782 X, konstanta $\mathrm{a}=$ dapat diartikan jika koreksi biaya entertainment $(\mathrm{X})$ adalah nol $(0)$, maka laba rugi (Y) adalah $-0,300$. Nilai koefisien $\mathrm{b}=2,783$ dapat diartikan jika setiap kenaikan koreksi fiskal biaya entertainment $(\mathrm{X})$ adalah satu (1), maka tingkat laba rugi (Y) akan meningkat 2,783.
\end{abstract}

Kata kunci: Koreksi Fiskal Biaya Entertainment, Laporan Laba Rugi

\section{Pendahuluan}

Kegiatan entertain merupakan salah satu kegiatan yang nampaknya agak sulit dilewatkan kepada lawan transaksi demi kelancaran kegiatan bisnis yang dilakukan.

Hal ini berarti diperlukan berbagai usaha yang cukup berarti untuk memberikan treatment lebih kepada lawan transaksinya, seperti jamuan makan, minum, menonton, karaoke, dan kegiatan lainnya. Semua biaya sehubungan dengan entertainment yaitu biaya representasi, jamuan dan sejenisnya yang dicatatkan dalam laporan komersial, belum tentu dapat dibebankan seluruhnya menjadi biaya fiskal sesuai ketentuan pajak yang berlaku sehingga Wajib Pajak melakukan sendiri koreksi di dalam SPT Tahunan PPh yang disampaikan ke kantor pajak.

Pada saat perusahaan mencatat pembebanan biaya entertainment secara fiskal, perlu diperhatikan ketetuan pajak yang berlaku. Di dalam Pasal 6 ayat (1) huruf a Undang-undang Nomor 7 Tahun 1983 tentang Pajak Penghasilan sebagaimana telah diubah terakhir dengan Undang-undang Nomor 17 Tahun 2000 dinyatakan bahwa besarnya Penghasilan Kena Pajak bagi Wajib Pajak dalam negeri dan bentuk usaha tetap, ditentukan berdasarkan penghasilan bruto dikurangi biaya untuk mendapatkan, menagih, dan memelihara penghasilan, termasuk biaya pembelian bahan, biaya berkenaan dengan pekerjaan atau jasa termasuk upah, gaji, honorarium, bonus, gratifikasi, dan tunjangan yang diberikan dalam bentuk uang, bunga, sewa, royalti, biaya perjalanan, biaya pengolahan limbah, premi asuransi, biaya administrasi, dan pajak kecuali Pajak Penghasilan.

Berdasarkan ketentuan diatas dijelaskan bahwa biaya yang dapat dikurangkan dari penghasilan secara fiskal yaitu benar ada hubungannya dengan kegiatan perusahaan untuk mendapatkan, menagih dan memelihara penghasilan perusahaan (materiil). Benar tidaknya ada hubungannya tersebut, perusahaan membuat daftar nominatif yang dilampirkan dalam Surat 
Pemberitahuan Tahunan. Biaya entertainment yang tercantum di daftar nominatif harus dapat dibuktikan dengan evidence atau bukti transaksi atas pengeluaran biaya tersebut, sebagaimana format dan pengisian daftar nominatif mengacu pada surat edaran SE - 27/PJ.22/1986. Selanjutnya, biaya entertainment, representasi, jamuan dan sejenisnya harus dapat dibuktikan bahwa biayabiaya tersebut telah benar-benar dikeluarkan (formal) dan diketahui bahwa pengeluaran tersebut telah sesuai dengan kelaziman dan kewajaran dalam praktek dunia usaha sesuai dengan adat kebiasaan pedagang yang baik serta dapat dibuktikan kebenaran.

Koreksi pengakuan biaya entertainment yang telah dikeluarkan secara laporan keuangan fiskal tentu harus menggunakan metode yang benar sesuai ketentuan perpajakan yang berlaku di Indonesia, tetapi tidak hanya diwajibkan untuk memenuhi ketentuan perpajakan, membayar dan melaporkan pajak, namun juga menyajikan dan mengungkapkan informasi tersebut dalam penggunaan laporan keuangan agar tidak salah dalam membaca laporan keuangan. Hasil penelitian yang telah dilakukan oleh Steven Kurniawan, Jenny Morasa dan Stanley Kho Walandouw (2017) bahwa perbandingan penerapan perencanaan pajak PPh Badan Menurut PT Bank SulutGo telah sesuai dengan ketentuan perpajakan. PT. Sarana Papan Seluncur Indonesia telah menerapkan PP 46 Tahun 2013 dalam laporan rekonsiliasi fiskal dalam menentukan PPh badan terutang (Amin Setio Lestiningsih, 2014)

\section{Tinjauan Literatur}

\subsection{Pengertian Koreksi Fiskal}

Rahayu (2017) menyimpulkan bahwa adanya perbedaan pengakuan penghasilan dan biaya antara akuntansi komersial dan akuntansi pajak (akuntansi fiskal), menimbulkan perbedaan dalam menghitung besarnya penghasilan kena pajak. Perbedaan ini disebabkan adanya perbedaan kepentingan antara akuntansi komersial yang mendasarkan laba pada konsep dasar akuntansi yaitu: the proper matching cost against revenue, sedang dari segi fiskal tujuan utamanya adalah penerimaan negara.

Secara definitif, pengertian Rekonsiliasi Fiskal adalah teknik pencocokan yang dilakukan yang dimaksudkan untuk meniadakan perbedaan antara laporan keuangan komersial (yang disusun berdasarkan prinsip akuntansi/PSAK) dengan peraturan perundang-undangan perpajakan, sehingga memunculkan koreksi fiskal atau penyesuaian/koreksi fiskal baik koreksi positif maupun negatif, dengan tujuan untuk menentukan jumlah laba usaha fiskal dan besarnya pajak terutang (Pohan, 2017)

\subsection{Jenis-Jenis Koreksi Fiskal}

Menurut Undang-Undang dasar hukum koreksi fiskal adalah UU No.36 tahun 2008 tentang Pajak Penghasilan (PPh)

\section{Koreksi Fiskal Positif}

Koreksi Fiskal Positif Yaitu koreksi fiskal yang menyebabkan penambahan penghasilan kena pajak dan PPh terutang. Jenis Koreksi Fiskal Positif antara lain :

a. Pembagian laba dengan nama dan dalam bentuk apapun seperti dividen, termasuk dividen yang dibayarkan oleh perusahaan asuransi kepada pemegang polis, dan pembagian sisa hasil usaha koperasi.

b. Biaya yang dibebankan atau dikeluarkan untuk kepentingan pribadi pemegang saham, sekutu, atau anggota.

c. Pembentukan atau pemupukan dana cadangan kecuali :

1) Cadangan piutang tak tertagih untuk usaha bank dan badan usaha lain yang menyalurkan kredit, sewa guna usaha dengan hak opsi, perusahaan pembiayaan konsumen, dan perusahaan anjak piutang.

2) Cadangan untuk usaha asuransi termasuk cadangan bantuan sosial yang dibentuk oleh Badan Penyelenggara Jaminan Sosial.

3) Cadangan penjaminan untuk Lembaga Penjamin Simpanan. 
4) Cadangan biaya reklamasi untuk usaha pertambangan.

5) Cadangan biaya penanaman kembali untuk usaha kehutanan.

6) Cadangan biaya penutupan dan pemeliharaan tempat pembuangan limbah industri untuk usaha pengolahan limbah industry.

d. Premi asuransi kesehatan, asuransi kecelakaan, asuransi jiwa, asuransi dwiguna, dan asuransi bea siswa, yang dibayar oleh Wajib Pajak orang pribadi, kecuali jika dibayar oleh pemberi kerja dan premi tersebut dihitung sebagai penghasilan bagi Wajib Pajak yang bersangkutan.

e. Penggantian atau imbalan sehubungan dengan pekerjaan atau jasa yang diberikan dalam bentuk natura dan kenikmatan, kecuali penyediaan makanan dan minuman bagi seluruh pegawai serta penggantian atau imbalan dalam bentuk natura dan kenikmatan di daerah tertentu dan yang berkaitan dengan pelaksanaan pekerjaan yang diatur dengan atau berdasarkan Peraturan Menteri Keuangan.

f. Jumlah yang melebihi kewajaran yang dibayarkan kepada pemegang saham atau kepada pihak yang mempunyai hubungan istimewa sebagai imbalan sehubungan dengan pekerjaan yang dilakukan.

g. Harta yang dihibahkan, bantuan atau sumbangan, dan warisan sebagaimana dimaksud dalam Pasal 4 ayat (3) huruf a dan huruf b, kecuali sumbangan sebagaimana dimaksud dalam Pasal 6 ayat (1) huruf i sampai dengan huruf $m$ serta zakat yang diterima oleh badan amil zakat atau lembaga amil zakat yang dibentuk atau disahkan oleh pemerintah atau sumbangan keagamaan yang sifatnya wajib bagi pemeluk agama yang diakui di Indonesia, yang diterima oleh lembaga keagamaan yang dibentuk atau disahkan oleh pemerintah, yang ketentuannya diatur dengan atau berdasarkan Peraturan Pemerintah.

h. Pajak Penghasilan.

i. Biaya yang dibebankan atau dikeluarkan untuk kepentingan pribadi Wajib Pajak atau orang yang menjadi tanggungannya.

j. Gaji yang dibayarkan kepada anggota persekutuan, firma, atau perseroan komanditer yang modalnya tidak terbagi atas saham.

k. Sanksi administrasi berupa bunga, denda, dan kenaikan serta sanksi pidana berupa denda yang berkenaan dengan pelaksanaan perundang-undangan di bidang perpajakan Persediaan yang jumlahnya melebihi jumlah berdasarkan metode penghitungan yang sudah ditetapkan dalam Pasal 10 UU No.36 Tahun 2008 tentang PPh.

1. Penyusutan yang jumlahnya melebihi jumlah berdasarkan metode penghitungan yang sudah ditetapkan dalam Pasal 10 UU No.36 Tahun 2008 tentang PPh.

$\mathrm{m}$. Biaya yang ditangguhkan pengakuannya.

2. Koreksi Fiskal Negatif

Yaitu koreksi yang menyebabkan pengurangan penghasilan kena pajak dan $\mathrm{PPh}$ terutang. Jenis Koreksi Fiskal Negatif antara lain :

a. $\quad$ Penghasilan yang telah dikenakan PPh Final antara lain :

1) Penghasilan berupa bunga deposito dan tabungan lainnya, bunga obligasi dan surat utang negara, dan bunga simpanan yang dibayarkan oleh koperasi kepada anggota koperasi orang pribadi.

2) Penghasilan berupa hadiah undian.

3) Penghasilan dari transaksi saham dan sekuritas lainnya, transaksi derivatif yang diperdagangkan di bursa, dan transaksi penjualan saham atau pengalihan penyertaan modal pada perusahaan pasangannya yang diterima oleh perusahaan modal ventura.

4) Penghasilan dari transaksi pengalihan harta berupa tanah dan/atau bangunan, usaha jasa konstruksi, usaha real estate, dan persewaan tanah dan/atau bangunan.

b. Penghasilan yang bukan merupakan objek pajak antara lain :

1) Bantuan atau sumbangan, termasuk zakat yang diterima oleh badan amil zakat atau lembaga amil zakat yang dibentuk atau disahkan oleh pemerintah dan yang diterima oleh penerima zakat yang berhak atau sumbangan keagamaan yang sifatnya wajib bagi pemeluk agama yang diakui di Indonesia, yang diterima oleh lembaga keagamaan yang dibentuk atau disahkan oleh pemerintah dan yang diterima oleh penerima sumbangan yang berhak, 
yang ketentuannya diatur dengan atau berdasarkan Peraturan Pemerintah sepanjang tidak ada hubungan dengan usaha, pekerjaan, kepemilikan, atau penguasaan di antara pihakpihak yang bersangkutan.

2) Harta hibahan yang diterima oleh keluarga sedarah dalam garis keturunan lurus satu derajat, badan keagamaan, badan pendidikan, badan sosial termasuk yayasan, koperasi, atau orang pribadi yang menjalankan usaha mikro dan kecil, yang ketentuannya diatur dengan atau berdasarkan Peraturan Menteri Keuangan sepanjang tidak ada hubungan dengan usaha, pekerjaan, kepemilikan, atau penguasaan di antara pihak-pihak yang bersangkutan.

3) Warisan.

4) Harta termasuk setoran tunai yang diterima oleh badan sebagai pengganti saham atau sebagai pengganti penyertaan modal.

5) Penggantian atau imbalan sehubungan dengan pekerjaan atau jasa yang diterima atau diperoleh dalam bentuk natura dan/atau kenikmatan dari Wajib Pajak atau Pemerintah, kecuali yang diberikan oleh bukan Wajib Pajak, Wajib Pajak yang dikenakan pajak secara final atau Wajib Pajak yang menggunakan norma penghitungan khusus (deemed profit).

6) Pembayaran dari perusahaan asuransi kepada orang pribadi sehubungan dengan asuransi kesehatan, asuransi kecelakaan, asuransi jiwa, asuransi dwiguna, dan asuransi bea siswa.

7) dividen atau bagian laba yang diterima atau diperoleh perseroan terbatas sebagai Wajib Pajak dalam negeri, koperasi, badan usaha milik negara, atau badan usaha milik daerah, dari penyertaan modal pada badan usaha yang didirikan dan bertempat kedudukan di Indonesia dengan syarat :

a) Dividen berasal dari cadangan laba yang ditahan.

b) Bagi perseroan terbatas, badan usaha milik negara dan badan usaha milik daerah yang menerima dividen, kepemilikan saham pada badan yang memberikan dividen paling rendah $25 \%$ (dua puluh lima persen) dari jumlah modal yang disetor.

8) Iuran yang diterima atau diperoleh dana pensiun yang pendiriannya telah disahkan Menteri Keuangan, baik yang dibayar oleh pemberi kerja maupun pegawai.

9) Penghasilan dari modal yang ditanamkan oleh dana pensiun sebagaimana dimaksud pada huruf $\mathrm{h}$, dalam bidang-bidang tertentu yang ditetapkan dengan Keputusan Menteri Keuangan.

10)Bagian laba yang diterima atau diperoleh anggota dari perseroan komanditer yang modalnya tidak terbagi atas saham-saham, persekutuan, perkumpulan, firma, dan kongsi, termasuk pemegang unit penyertaan kontrak investasi kolektif.

11)Penghasilan yang diterima atau diperoleh perusahaan modal ventura berupa bagian laba dari badan pasangan usaha yang didirikan dan menjalankan usaha atau kegiatan di Indonesia, dengan syarat badan pasangan usaha tersebut :

a) Merupakan perusahaan mikro, kecil, menengah, atau yang menjalankan kegiatan dalam sektor-sektor usaha yang diatur dengan atau berdasarkan Peraturan Menteri Keuangan.

b) Sahamnya tidak diperdagangkan di bursa efek di Indonesia.

12)Beasiswa yang memenuhi persyaratan tertentu yang ketentuannya diatur lebih lanjut dengan atau berdasarkan Peraturan Menteri Keuangan.

13)Sisa lebih yang diterima atau diperoleh badan atau lembaga nirlaba yang bergerak dalam bidang pendidikan dan/atau bidang penelitian dan pengembangan, yang telah terdaftar pada instansi yang membidanginya, yang ditanamkan kembali dalam bentuk sarana dan prasarana kegiatan pendidikan dan/atau penelitian dan pengembangan, dalam jangka waktu paling lama 4 (empat) tahun sejak diperolehnya sisa lebih tersebut, yang ketentuannya diatur lebih lanjut dengan atau berdasarkan Peraturan Menteri Keuangan.

14)Bantuan atau santunan yang dibayarkan oleh Badan Penyelenggara Jaminan Sosial kepada Wajib Pajak tertentu, yang ketentuannya diatur lebih lanjut dengan atau berdasarkan Peraturan Menteri Keuangan.

15)Persediaan yang jumlahnya kurang jumlah berdasarkan metode penghitungan yang sudah ditetapkan dalam Pasal 10 UU No.36 Tahun 2008 tentang PPh. 
16)Penyusutan yang jumlahnya kurang jumlah berdasarkan metode penghitungan yang sudah ditetapkan dalam Pasal 10 UU No.36 Tahun 2008 tentang PPh.

Istilah positif dan negatif ini tidak merujuk pada tanda (+) ataupun (-), Tapi pada penghasilan kena pajak. Artinya, Koreksi Positif akan mengakibatkan penghasilan kena pajak meningkat, sedangkan koreksi negatif menghasilkan penghasilan kena pajak menurun. Tabel berikut merinci kedua koreksi fiskal tersebut :

Tabel 1. Koreksi Fiskal

\begin{tabular}{|c|c|c|c|}
\hline \multirow{2}{*}{ JenisKoreksiFiskal } & \multicolumn{3}{|c|}{ LaporanKomersilvsLaporanFiskal } \\
\hline KoreksiPositif & Penghasilan & $<$ & Penghasilan \\
\hline & Biaya & $>$ & Biaya \\
\hline KoreksiNegatif & Penghasilan & $>$ & Penghasilan \\
\hline & Biaya & $<$ & Biaya \\
\hline
\end{tabular}

Sumber : Team IAI Modul Pelatihan Pajak Terapan Brevet AB Terpadu, 2015

\subsection{Biaya Entertaiment}

Biayapelayanan atau sering disebut biaya entertainment yang biasa digunakan oleh perusahaan untuk menjamu klien dalam rangka membina hubungan baik kerjasama. Namun tentunya pembebanan ini harus berdasarkan aturan perpajakan.

Dasar aturannya yaitu: Surat Edaran DJP No. SE-27/PJ.22/1986, tanggal 14 Juni 1986. Biaya entertainment/jamuan/representatif mempunyai syarat tertentu agar biaya yang dikeluarkan oleh suatu perusahaan untuk entertainment/jamuan/representative tersebut dapat dikurangkan dari penghasilan bruto perusahaan dalam menentukan laba fiskal sebagai dasar pengenaan pajak penghasilan sesuai dengan surat edaran yaitu biaya yang dikeluarkan tersebut merupakan biaya untuk mendapatkan, menagih, dan memelihara penghasilan dan harus melampirkan daftar nominatif dalam SPT Tahunan PPh pada tahun pajak yang bersangkutan. Daftar nominatif entertainment terdiri dari:

1. Nomor urut

2. Tanggal diberikannya entertainment

3. Nama/tempat entertainment diberikan

4. Alamat entertainment

5. Jumlah biaya entertainment

6. Relasi : nama, posisi, nama perusahaan,jenis usaha.

Adapun poin-poin tersebut di atas disajikan di dalam format tabel berikut:

Tabel 2. LampiranDaftarNominatifSesuai SE- 27/PJ.22/1986

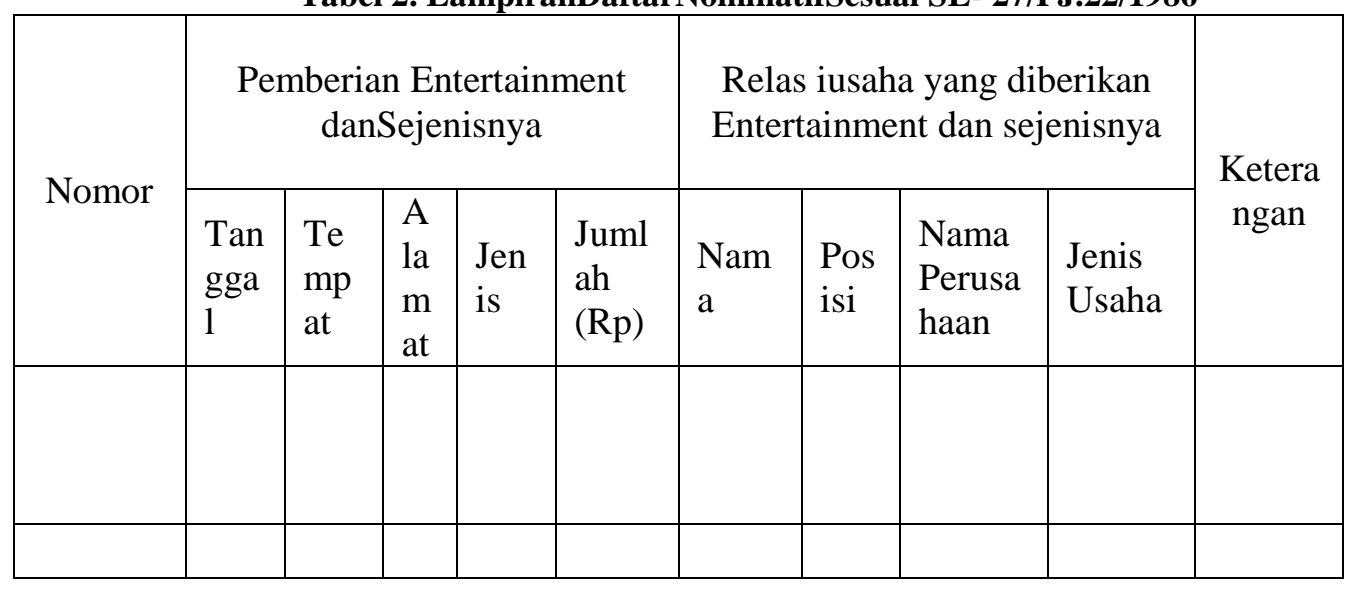

Sumber :http://www.ortax.orgBiayaEntertainment, 2016 


\subsection{Ketentuan Lain Untuk Biaya Entertainment}

Adapun ketentuan lainnya yang perlu diperhatikan adalah sebagai berikut:

Pada dasarnya biaya entertainment merupakan biaya yang dikeluarkan untuk pihak eksternal, maka biaya entertainment untuk pihak internal tidak dapat dijadikan biaya fiskal.

Petugas pajak yang melakukan penelitian atau pemeriksaan terhadap Surat Pemberitahuan Tahunan menemukan pos biaya entertainment dan sejenisnya, maka kepada Wajib Pajak dimintakan daftar nominatif untuk membuktikan, bahwa biaya-biaya tersebut benar-benar telah dikeluarkan dan benar ada hubungannya dengan kegiatan perusahaan untuk mendapatkan, menagih dan memelihara penghasilan perusahaan. Pada prinsipnya daftar nominatif atas pengeluaran biaya entertainment harus dilampirkan pada Surat Pemberitahuan Tahunan, namun apabila Wajib Pajak tidak melampirkannya, Wajib Pajak harus dapat memberikannya pada saat dilakukan pemeriksaan oleh petugas pajak. Meskipun demikian biaya entertainment tersebut tetap diakui sebagai biaya perusahaan sepanjang memenuhi kriteria.

\subsection{Pengertian Laporan Laba Rugi}

Menurut (Marwansyah, 2017)laporan laba rugi merupakan laporan keuangan yang menggambarkan hasil usaha perusahaan dalam suatu periode tertentu.

\section{Metodologi}

Penelitian ini menggunakan metode kuantitatif dimana dalam pengolahan data menggunakan program SPSS versi 21 untuk menguji koefesien korelasi, uji koefesien determinasi, uji t, uji persamaan regresi.

\section{Hasil dan Diskusi}

\subsection{Populasi dan Sampel}

Berdasarkan data yang diperoleh di PT Berkah Karunia Kreasi,populasi yang digunakan dalam penelitian ini adalah laporankeuangan. Dan yang dijadikan sampel adalah laporan laba rugi 6 (Enam) tahun terakhir yaitu tahun 2012 sampai dengan 2017 dari biaya entertaiment yang belum di terapkan sebagaimana mestinya sesuai dengan peraturan perundang-undangan di Indonesia sehingga akibat dari dampak tersebut menimbulkan laba semakin tinggi karena di dalam perpajakan biaya entertainment jika tidak ada bukti yang jelas maka akan di kenakan koraksi fiskal positif dan tidak dapat diakui sebagai biaya fiskal, dikarenakan tidak dapat diakui sebagai biaya maka dalam laporan keuangan hal tersebut bisa merugikan perusahaan.

\subsection{Data Koreksi Fiskal Biaya Entertainment (Variabel X)}

Data atas koreksi fiskal positif Biaya Entertainment PT Berkah Karunia Kreasi untuk periode 2012 - 2017 dapat di lihat dari tabel berikut :

Tabel 3. Koreksi Fiskal Biaya Entertaiment

\begin{tabular}{|c|c|}
\hline Tahun & \multicolumn{1}{|c|}{ KoreksiFiskalBiayaEntertainment } \\
\hline 2012 & Rp. 15.008 .829 \\
\hline 2013 & Rp. 30.668 .990 \\
\hline 2014 & Rp. 48.869 .600 \\
\hline 2015 & Rp. 46.064 .000 \\
\hline 2016 & Rp. 50.000 .000 \\
\hline 2017 & Rp. 71.213.624 \\
\hline TOTAL & Rp. 261.825.043 \\
\hline
\end{tabular}

Sumber : Tax Accounting PT. Berkah Karunia Kreasi 


\subsection{Data Laba Rugi Setelah Koreksi Fiskal (Variabel Y)}

Data Laba Rugi Setelah di koreksi fiskal positif PT Berkah Karunia Kreasi untuk periode 2012 - 2017 dapat di lihat dari tabel berikut :

Tabel 4. Laba Rugi Setelah Koreksi Fiskal

\begin{tabular}{|l|l|l|}
\hline No & Tahun & \multicolumn{1}{c|}{ RealisasiLabaRugi } \\
\hline 1 & 2012 & Rp. 35.795 .479 \\
\hline 2 & 2013 & Rp. 76.558 .960 \\
\hline 3 & 2014 & Rp. 172.749 .598 \\
\hline 4 & 2015 & Rp. 112.731 .608 \\
\hline 5 & 2016 & Rp. 1.148 .587 .009 \\
\hline 6 & 2017 & Rp. 2.835.934.093 \\
\hline & TOTAL & Rp. 4.382.356.747 \\
\hline
\end{tabular}

Sumber : Tax Accounting PT. Berkah Karunia Kreasi

Untuk memudahkan peneliti melakukan pengujian dan analasis data maka peneliti menggunakan angka persentase data koreksi fiskal biaya entertainment $(\mathrm{X})$ maupun laba rugi (Y) sebagai berikut:

Tabel 5. Data PersentaseVaribel X dan Y

\begin{tabular}{|c|c|c|c|c|l|l|c|}
\hline $\begin{array}{c}\mathrm{N} \\
\mathrm{o}\end{array}$ & $\begin{array}{c}\text { Tahu } \\
\mathrm{n}\end{array}$ & $\begin{array}{c}\text { RealisasiKoreksi } \\
\text { FiskalBiaya } \\
\text { Entertainment }\end{array}$ & $\%$ & $\begin{array}{c}\text { Variab } \\
\text { el X }\end{array}$ & RealisasiLabaRugi & $\%$ & $\begin{array}{c}\text { Varia } \\
\text { bel Y }\end{array}$ \\
\hline 1 & 2012 & Rp. 15.008 .829 & $6 \%$ & 0,06 & Rp. 35.795 .479 & $1 \%$ & 0,01 \\
\hline 2 & 2013 & Rp. 30.668 .990 & $12 \%$ & 0,12 & Rp. 76.558 .960 & $2 \%$ & 0,02 \\
\hline 3 & 2014 & Rp. 48.869 .600 & $19 \%$ & 0,19 & Rp. 172.749 .598 & $4 \%$ & 0,04 \\
\hline 4 & 2015 & Rp. 46.064 .000 & $18 \%$ & 0,18 & Rp. 112.731 .608 & $3 \%$ & 0,03 \\
\hline 5 & 2016 & Rp. 50.000 .000 & $19 \%$ & 0,19 & Rp. 1.148 .587 .009 & $26 \%$ & 0,26 \\
\hline 6 & 2017 & Rp. 71.213 .624 & $27 \%$ & 0,27 & Rp. 2.835 .934 .093 & $65 \%$ & 0,65 \\
\hline \multicolumn{2}{|c|}{ TOTAL } & Rp. $\mathbf{2 6 1 . 8 2 5 . 0 4 3}$ & $\mathbf{1 0 0 \%}$ & $\mathbf{1 , 0 1}$ & Rp. $\mathbf{4 . 3 8 2 . 3 5 6 . 7 4 7}$ & $\mathbf{1 0 0 \%}$ & $\mathbf{1 , 0 1}$ \\
\hline
\end{tabular}

\subsection{Analisis Pengaruh Koreksi Fiskal Biaya Entertainment $(X)$ terhadap Laba Rugi (Y) 4.4.1 Uji Koefesien Korelasi}

Berdasarkan pengolahan data menggunakan SPPS versi 21, maka hasil uji koefisien korelasi dapat dilihat pada tabel berikut:

Tabel 6. Hasil Uji Koefisien Korelasi

Correlations

\begin{tabular}{|ll|r|r|}
\hline & & $\begin{array}{c}\text { KoreksiFiskal By } \\
\text { Entertainment }\end{array}$ & LabaRugi \\
\hline KoreksiFiskal By & Pearson Correlation & 1 &, 781 \\
Entertainment & Sig. (2-tailed) & &, 067 \\
& $\mathrm{~N}$ & 6 & 6 \\
LabaRugi & Pearson Correlation &, 781 & 1 \\
& Sig. (2-tailed) &, 067 & 6 \\
\hline
\end{tabular}

Sumber: SPPS Ver 21 
Pada Tabel 6 menunjukkan besarnya hubungan antar variabel koreksi fiskalbiaya entertainment dengan laba rugi pada laporan keuangan PT Berkah Karunia Kreasi yang dihitung menggunakan koefisien korelasi adalah 0,781. Hal ini menunjukkan hubungan yang tinggi atau kuat sesuai dengan tabel interpretasi korelasi.

\subsubsection{Uji Koefisien Determinasi}

Berdasarkan pengolahan data menggunakan SPPS versi 21, maka hasil uji koefisien determinasi dapat dilihat pada tabel berikut:

Tabel 7. Hasil Uji Koefesien Determinasi

Model Summary

\begin{tabular}{|l|r|r|r|r|}
\hline Model & \multicolumn{1}{|c|}{$\mathrm{R}$} & \multicolumn{1}{|c|}{ R Square } & Adjusted R Square & \multicolumn{1}{c|}{$\begin{array}{c}\text { Std. Error of the } \\
\text { Estimate }\end{array}$} \\
\hline 1 &, $781^{\mathrm{a}}$ &, 610 &, 513 &, 17742 \\
\hline
\end{tabular}

Sumber:SPSS Ver 21

Pada tabel 7 diketahui bahwa $\mathrm{R}$ yang diperoleh sebesar 0,610 yang dalam hal ini berarti $61 \%$ dari laba rugi bisa dijelaskan oleh variabel koreksi fiskal biaya entertainment. Sedangkan 39\% dijelaskan oleh faktor-faktor lain yang tidak diteliti.

\subsubsection{Uji t}

Berdasarkan pengolahan data menggunakan SPPS versi 21, maka hasil uji koefisien determinasi dapat dilihat pada tabel berikut:

Tabel 8. Hasil Uji t

Coefficients $^{\mathrm{a}}$

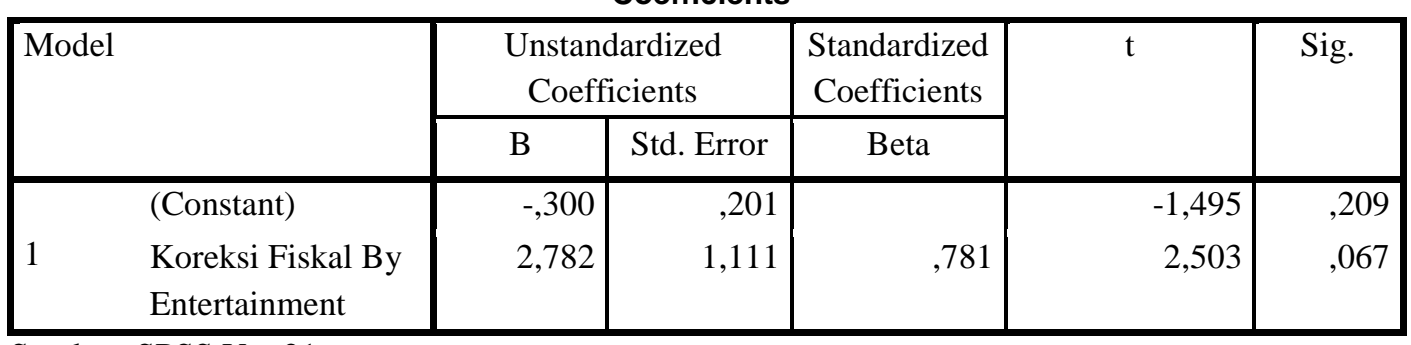

Sumber: SPSS Ver 21

Berdasarkan tabel 8 diketahui tingkat signifikan adalah 0,067 >0,05 maka keputusannya adalah koreksi fiskal biaya entertainment berpengaruh tidak signifikan terhadap laba rugi. Berdasarkan hasil uji t pada tabel 8 dapat diketahui nilai thitung, yang akan dibandingkan dengan ttabel, maka kriteria yang dibuat oleh peneliti sebagai berikut :

1. Jika thitung > ttabel, maka $\mathrm{H}_{0}$ ditolak dan $\mathrm{H}_{1}$ diterima

2. Jika thitung < ttabel, maka $\mathrm{H}_{0}$ diterima dan $\mathrm{H}_{1}$ ditolak

Pada penelitian ini, terlebih dahulu kita mencari ttabel, dimana jumlah variabel yang diuji 2 variabel serta jumlah data 6 maka derajat bebasnya adalah 4 dengan tingkat signifikansi 0.05 , maka ttabelnya adalah 2,131 . Hasil kesimpulan yang dapat ditarik dari uji $\mathrm{t}$ adalah $\mathrm{H}_{0}$ ditolak dan $\mathrm{H}_{1}$ diterima, yang berarati ada pengaruh koreksi fiskal biaya entertainment terhadap laba rugi tapi tidak signifikan.

\subsubsection{Persamaan Regresi}

Berdasarkan pengolahan data menggunakan SPPS versi 21, maka hasil uji koefisien determinasi dapat dilihat pada tabel berikut: 
Tabel 9. Persamaan Regresi

Coefficients $^{a}$

\begin{tabular}{|c|c|c|c|c|c|c|}
\hline \multirow{2}{*}{\multicolumn{2}{|c|}{ Model }} & \multicolumn{2}{|c|}{$\begin{array}{l}\text { Unstandardized } \\
\text { Coefficients }\end{array}$} & $\begin{array}{l}\text { Standardized } \\
\text { Coefficients }\end{array}$ & \multirow[t]{2}{*}{$\mathrm{t}$} & \multirow[t]{2}{*}{ Sig. } \\
\hline & & $B$ & $\begin{array}{l}\text { Std. } \\
\text { Error }\end{array}$ & Beta & & \\
\hline \multirow[b]{2}{*}{1} & (Constant) &,- 300 & 201 & \multirow[b]{2}{*}{,781 } & $-1,495$ & ,209 \\
\hline & $\begin{array}{l}\text { KoreksiFiskal By } \\
\text { Entertainment }\end{array}$ & 2,782 & 1,111 & & 2,503 & ,067 \\
\hline
\end{tabular}

Sumber: SPSS Ver 21

Pada tabel 9 diketahui nilai konstanta $\alpha$ sebesar -0,300 dan nilai koefisien b adalah 2,782 maka dapat diperoleh bentuk persamaan regresi linear sederhana yaitu:

$$
Y=-0,300+2,782 X
$$

Pada persamaan regresi tersebut dapat ditarik kesimpulan bahwa nilai konstanta $\alpha=-0,300$ dapat diartikan jika koreksi fiskal biaya entertainment (X) nilainya nol (0), maka tingkat laba rugi (Y) adalah sebesar -0,300. Nilai koefisien b sebesar 2,782 dapat diartikan jika setiap peningkatan persepsi koreksi fiskal biaya entertainment (X) sebesar satu (1), maka tingkat laba rugi (Y) akan meningkat 2,782. Dengan kata lain dengan adanya koreksi fiskal atau biaya entertainment mengakibatkan meningkatnya laba perusahaan sehingga menjadikan pajak penghasilan lebih besar maka pengguna laporan keuangan harus memperhatikan skala tersebut untuk memanfaatkan biaya yang sudah dikeluarkan sebagaimana diambil contoh dari tempat peneliti melakukan riset.

\section{Kesimpulan}

Berdasarkan data yang digunakan dan penelitian yang telah dilakukan, kesimpulan yang dapat diambil sebagai berikut:

1. Koreksi fiskal biaya entertainment berpengaruh terhadap laba rugi perusahaan PT Berkah Karunia Kresi tidak signifikan karena dengan nilai signifikan 0,067 >0,05.

2. Koreksi fiskal biaya entertainment berpengaruh tetapi tidak signifikan terhadap laba rugi pada PT Berkah Karunia Kreasi dengan hasil thitung $=2,503$ lebih besar dari ttabel $=2,131$ (thitung> ttabel).

3. Dari hasil uji regresi sederhana dapat diketahui nilai konstanta $\alpha$ adalah $-0,300$ artinya apabila koreksi fiskal biaya entertainment adalah nol (0), maka laba rugi adalah Rp. -0,300. Sedangkan nilai koefisien regresi adalah sebesar 2,782 maka dapat dikatakan apabila koreksi fiskal biaya entertainmentmengalami peningkatan Rp.1, maka laba rugi meningkat Rp.2,782. Hal ini menunjukkan makin tinggi koreksi fiskal biaya entertainment maka makin tinggi pula laba rugi pada perusahaan PT Berkah Karunia Kreasi. 


\section{DAFTAR PUSTAKA}

[1] katan Akuntansi Indonesia. (2015). Modul Pelatihan Pajak Terapan Brevet AB Terpadu. Jakarta: Ikatan Akuntansi Indonesia

[2] Kurniawan, Steven, Jenny Morasa, Stanley Kho Walandoow. (2017). Evaluasi Penerapan Perencanaan Pajak Atas Pajak Penghasilan (PPh Pasal 25) Pada PT. Bank SulutGo. Jurnal Riset Akuntansi Going Concern 12 (1) 2017

[3] Lestiningsih, Amin Setio. (2014). Penerapan PP. 46 Tahun 2013 Dalam Laporan Rekonsiliasi Fiskal Sebagai Dasar Untuk Menghitung PPh Badan Pasal 29 Terutang. Jurnal Moneter Vol 1 No 2 Oktober 2014.

[4] Marwansyah, Sofyan. (2017). Analisis Current Ratio Terhadap Debt To Asset Ratio Pada Perusahaan Property Dan Real Estate. Jurnal Moneter, Vol 4 No 1 April 2017

[5] Ortax, Tim Redaksi, Taxlearning | Retrieved Mei 12, 2018, from http://www.ortax.org/ortax/?mod=studi\&page=show\&id=81

[6] Pohan, C. A. (2017). Pembahasan Komprehensif Perpajakan Indonesia (2nd ed.). Mitra Wacana Media.

[7] Rahayu, S. K. (2017). Perpajakan Konsep dan Aspek Formal (1st ed.). Bandung: Rekayasa Sains.

[8] Undang-Undang Republik Indonesia Nomor 36 Tahun 2008 Tentang Perubahan Keempat Atas Undang-Undang Nomor 7 Tahun 1983 Tentang Pajak Penghasilan

[9] Surat Edaran Direktur Jenderal Pajak Nomor SE - 27/PJ.22/1986 tentang Biaya "Entertainment" dan Sejenisnya (Seri PPh Umum 18) 